\title{
The Implementation of Computer-Based administrative Information Systems to Improve the Performance of Services Quality in Hospitals
}

\author{
Inri Takain ${ }^{1}$, Katmini ${ }^{2}$ \\ ${ }^{1}$ Hospital Administration \\ Management \\ ${ }^{2}$ Master of Public Health Study \\ Program, Institute of Public \\ Health Sciences Strada \\ Indonesia \\ Email: \\ inri.takain@gmail.com1
}

Received : October $4^{\text {nd }} 2021$

Accepted : October $15^{\text {rd }} 2021$

Published : November $27^{\text {th }} 2021$

\begin{abstract}
Background SIMRS is a communication information technology system that processes and integrates the entire flow of hospital service processes in forms of coordination network, reporting and administrative procedures to obtain precise and accurate information and is part of the Health Information System. The purpose of this study was to identify how to implement computer-based administrative information systems to improve service quality performance in hospitals. The method applied in this study was a literature study to examine journal articles regarding the Implementation of Computer-Based Administrative Information Systems to Improve Service Quality Performance in Hospitals, data collection used was secondary data. The results of 20 literature journal articles study showed that the implementation of SIMRS has not run efficiently or has problems. This is because the SIMRS implemented by the hospital was considered less attention by related parties and they have not properly prepared all related to SIMRS (i.e. many officers do not understand because there are no support, supervision and evaluation from the management and technology that has not been running maximally). Conclusion, based on the Literature Review on the Implementation of Computer-Based Administrative Information Systems to Improve Service Quality Performance in Hospitals were found there were obstacles in implementing computer-based information systems, including lack of personnel, less skilled, less disciplined and less responsible personnel, facilities and infrastructure constraints (less stable Wi-Fi network and crashed system) and obstacles from the management (no training and proper SOP). To deal with these problems, IT knowledge training to the employees, improving the system and applying proper SOP should be applied so that information systems can be implemented and used in order to help simplify the work and improve service quality in hospitals in the future.
\end{abstract}

Keywords: HIMS evaluation and service performance, HIMS implementation, SIMRS implementation

Copyright @ 2021 IIK STRADA Indonesia All right reserved. International License. 


\section{INTRODUCTION}

In the current era of globalization, hospitals are required to improve performance and competitiveness as a business entity without reducing the social mission it carries. Hospitals must formulate strategic policies, including internal efficiency (organization, management, and human resources) and must be able to quickly and accurately make decisions to improve services to the community in order to become a responsive, innovative, effective, efficient and profitable organization. Hospital Management Information System is a computerized system that processes and integrates the entire flow of health care business processes in the form of a network of coordination, reporting and administrative procedures to obtain information quickly, precisely and accurately. A computer-based Management Information System (MIS) is a very important support tool, even absolute for hospital operations. Various experiences of hospitals using conventional administrative systems show that there are many lost opportunities to earn profits due to weak coordination between departments and the lack of fast, precise, accurate, and integrated information support.

Hospitals need good administrative personnel to manage the performance of workers in the health sector. Health administration places more emphasis on financial arrangements, staffing and patient admissions. To facilitate hospital health administration procedures, a system is needed that can provide convenience in the smooth administration of the process. Therefore, health administration is made through an administrative information system or AIS. The health administration information system is an information system that plays a role in the administrative process, such as the process of recording, counting, and correspondence. For example, a patient who will leave the hospital will receive a letter from the doctor or the administration department to make the administrative process easier.

The existence of this administrative information system is expected to provide convenience for employees and other officers in serving health services and is expected to improve employee performance as well. Therefore, the implementation of information systems is very important for every successful work process, where the data processing process uses computer technology with an integrated Hospital Administration Information System.

The implementation of SIM-SR has also been mandated by Law Number 36 of 2009 concerning Health which has mandated that to carry out effective and efficient health efforts, health information is required which is organized through information systems and across sectors. Every health facility operator, including those providing health service facilities, must provide health information system infrastructure, including institutional devices, technology, and human resources of PP Article 45 No. 46 of 2014.

According to one of the research journals Mellatul Husni and Deni Maisa Putra (2019), research on Analysis of Hospital Management Information System Implementation (SIMRS) in the Medical Record Work Unit at Rsu 'Aisyiyah Padang uses the HOT-Fit model, in the application of MIS medical records in general has been going well, although in some components there are still shortcomings, an explanation of the results of the medical record SIM analysis in each component, in the human component, the officer is less responsible and disciplined in the process of inputting patient data so that the resulting data is not accurate and complete.

Based on the results of this literature review, the problem is that the lack of SIMRS application in service performance, the purpose of the researcher is to find out how to implement a computer-based hospital administrative information system to improve the performance of service quality that is being developed or run and how the benefits for improving employee performance are. Due to large hospitals, information systems have become mandatory and become very complex.

\section{MATERIALS AND METHODS}

In accordance with the research objectives, namely to "identify how to implement a computer-based administrative information system to improve service quality performance in hospitals", the type of research used is Literature Review. The source used in the Literature Review is secondary data, which is obtained from articles or previous journals or internet sites that match the published topics (Zed, 2008; Embun, 2012). Literature study is another term for literature review, literature review, theoretical study, theoretical basis has been literature (literature review) and theoretical (Embun, 2012). 
In the research data of the 19 articles, there are several groups of articles that use quantitative and qualitative research methods in which they still contain the implementation of computer-based administrative information systems to improve service quality performance in hospitals.

The journals used in the literature review were obtained through the database of international pubmed journal providers, prayer, semantic scholar and Indonesian scientific journals through Google Scholar. The researcher wrote down the keywords according to the mesh (medical subject heading) namely "IMRS Implementation, HIMS Implementation, HIMS Evaluation and Service Performance". Article search by limiting from 2010 to 2020 which is accessed in full text in pdf format. The number of articles found was 434,744 in the selection < 10, the last 117,355 articles were identified. From the identification of 117,275 irrelevant articles, further selection was carried out and found 65 eligible fulltext articles. The final result of the selection was 19 articles that were included. Of these 19 articles, there are 15 study articles in Indonesia, 2 articles in Iran, and 2 articles in India. The research results from these 19 articles used qualitative and quantitative research methods.

\section{RESULTS}

The results of the search for this Literature Review article, the authors took journals from pubmed, prayer, semantic scholar and google scholar. At the initial stage, the articles collected amounted to 434,744 articles using the keywords "IMRS Implementation, HIMS Evaluation and Service Performance". After identifying the relevant titles, only 19 articles that were read were of good quality because the research methods were more complete, consisting of national journals and international journals.

Of the 19 articles that met the inclusion criteria, the discussion was based on the topic of a literature review, namely factors related to the Implementation of a Commuter-Based Administrative Information System to Improve Service Quality Performance in Hospitals. The journals used as references are as follows:

National Journal :

Dedi Irawan, M.E., Sy., Siska Novita (2014) Management Information System of Harapan Bunda Hospital Pringsewu Lampung. The method used is literature study, analysis method and design method. The analytical method is used to examine the problems faced by the hospital. The design method is used to design a new system that can solve the problems encountered. The results achieved are the production of reports related to data processing and display screens that can be used to process the data. The conclusion of this research is that it is hoped that the new system can provide convenience to the parties involved in processing data quickly and accurately, and can store data safely so as to assist in the service process to the community.

Mellatul Husni and Deni Maisa Putra (2019) Analysis of the Implementation of the Hospital Management Information System (SIMRS) in the Medical Record Work Unit at the 'Aisyiyah Hospital Padang. This study uses a qualitative descriptive method, collecting data by means of indepth interviews with participants. The participants in this study were the Head of Medical Records, Medical Records Officers, BPJS officers, and IT officers. Results: The application of a medical record SIM in terms of technology is quite good, although in the implementation of a medical record SIM there are still some obstacles but as long as it is not too urgent it is still can be overcome. In the technology component at RSU'Aisyiyah the officers have tried to make the medical record SIM run smoothly. Conclusion: Based on research analyzing the Hospital Management Information System (SIMRS) at the Medical Record Work Unit at RSU'Aisyiyah Padang using the HOT-Fit model, in the application of the medical record SIM in general it has been going well, although in some components there are still shortcomings, explanation the results of the analysis of the medical record SIM in each component, on the human component, officers are less responsible and disciplined in the process of inputting patient data so that the resulting data is not accurate and complete.

Andika Bayu Saputra (2016) Identification of Success Factors in Hospital Management Information System Implementation. This research is descriptive with a quantitative approach. Primary data collection used a questionnaire that was compiled based on data from the literature and papers related to HOT-Fit. The results obtained are the variables that affect the success of SIMRS implementation are in terms of technology variables, namely system quality, information quality and service quality, while in terms of human variables, namely user satisfaction affects the use of the system, in terms of organizational variables, namely the structure greatly affects the existing 
organizational environment. Conclusion: The implementation of SIMRS in PKU Muhammadiyah Temanggung Hospital still has some minor weaknesses that are not difficult to overcome. Some of the evaluations found were that the system still had errors during busy service hours, causing service activities to be hampered. Lack of personnel to handle system problems. Users who still do not understand how to use the system.

Marsiana Afonso, Dewi Ariyani Wulandari, Ronald (2017) Analysis of Hospital Management Information System Implementation at Kindergarten III Hospital 04.06.03 Dr.R.Soetarto Yogyakarta. The design in this study is a qualitative research with a case study approach. Smartphone support instruments and field notes. This study uses several techniques in data collection, namely in-depth interviews and documentation. Data analysis in this study uses interactive analysis of data reduction, data presentation, and conclusion drawing. Hospital Results TK III 04.06.03 Dr. R. Seotarto Yogyakarta has incomplete infrastructure, one of which is a computer. Meanwhile, the support from the managerial side has been very supportive. The availability of human resources in this hospital is still lacking because the average employees are civil servants and military so that their IT mastery is not so deep. The biggest obstacles in implementing the hospital management information system (SIM-RS) are funding, lack of infrastructure and human resources.

Sadriani Hade, Abidin Djalla, Ayu Dwi Putri Rusman (2019) Analysis of the Application of Hospital Management Information Systems in an Effort to Improve Health Services at the Andi Makkasau Hospital Parepare, Field observation/survey method (descriptive observation). In the survey method, direct interviews with the hospital and related parties will be conducted. The results showed that there was a difference between before and after the SIM-RS was introduced. Hospitals are expected to be able to maintain and develop the use of health service information technology for the community. Based on the results of the previous research and discussion, it can be concluded that the Management Information System at the Andi Makkasau Regional General Hospital Parepare has been running well, this can be seen from the smooth service to patients.

Tiara Khairani, Heru Susilo, Riyadi (2013) Implementation of a Computer-Based Hospital Administration Information System to Improve Employee Performance (Study at Billing Systems Hospital Dr. Saiful Anwar Malang) This study uses qualitative research methods. general and rather broad. The information submitted by the participants is then collected. The information is usually in the form of words or text. The data in the form of words or text are then analyzed. The result of this research is that the implementation of the hospital administration information system has been implemented since 1995 using Billing Systems. There is an increase in employee performance, namely being able to complete work faster, minimizing errors and being able to complete work in accordance with the specified time. Conclusion: after doing research at Dr. General Hospital. Saiful Anwar Malang on the implementation of computer-based administrative information systems, it can be concluded that:

1. Dr. General Hospital. Saiful Anwar Malang is a regional hospital that is fully accredited and ISO 9001 certified

2. The implementation of the hospital administration information system has an impact on improving employee performance. With the Billing System, errors that usually occur when manual is minimized. Etc

Indriana Novita Suprapto, Wahyu Sulistiadi, Samijatun, Ismail Sangadji (2018) Analysis of the Application of Information Technology Systems on the Performance of Outpatient Health Services at the Indonesian Christian University General Hospital The design of this study uses a type of descriptive research method with a cross-sectional approach., namely the researcher only observes and measures variables at one particular moment. The results of the document study containing the hospital flow system indicate that the service flow system for patients at the Indonesian Christian University General Hospital, both as a whole and outpatient, has been in accordance with the service flow instructions set by the Director General Yamed of the Indonesian Ministry of Health in 1997. Based on the results of the study and the discussion in the previous chapter, it can be concluded from this research as follows:

1. The average length of waiting time for patients in the outpatient unit of the Indonesian Christian University General Hospital is 52 (fifty two) minutes, which is in accordance 
with the minimum service time standard regulated by the Decree of the Minister of Health Number 129/MENKES/SK/II /2008, which is less or equal to sixty minutes or one hour.

2. The average satisfaction level of outpatients at the Indonesian Christian University General Hospital is $90 \%$ (ninety percent), which is in accordance with the minimum satisfaction standard that has been regulated by the Decree of the Minister of Health Number 129/Menkes/SK/II/2008, that the level of patient satisfaction in the outpatient unit must be more or equal to $90 \%$ (ninety percent). ETC

Darmawanti, Idawati ( 2019) Analysis of the Quality of Management Information Systems at the General Hospital of dr. Fauziah Bireun, This type of research is descriptive qualitative with interview method. The main informants in this study were the director, SIMRS installation head, SIMRS staff and SIMRS operators while triangulation informants were health service recipients. The results of in-depth interviews with directors, SIMRS installation heads, SIMRS staff and SIMRS operators regarding the infrastructure to support the implementation of SIMRS, it can be concluded that key informants (director, SIMRS installation head, SIMRS staff and SIMRS operator) know that the provision of computer equipment is not evenly distributed in every room and that there are damaged computers that take a long time to repair. Provision of advice and infrastructure, cable connectors and wifi are adjusted to the number of computers procured from each room. When running SIMRS, server problems often occur, especially if access is congested, the server is often slow. The quality of SIMRS in terms of infrastructure is not adequate. The quality of SIMRS in terms of HR, it was found that the number of HR was adequate except for programmers, there was no provision of routine training to improve HR competence, indiscipline of officers, no rewards and punishments. each HR

Evi Maya Odelia (2018) Organizational Capacity Development Through the Implementation of Hospital Management Information System (SIMRS) to Improve the Quality of Health Services at RSUD dr. Mohamad Soewandhie Surabaya. This research method uses a qualitative approach with a descriptive type. The technique of determining the informants used purposive techniques for internal parties of RSUD dr. Mohamad Soewandhie Surabaya and accidental technique for dr. Mohamad Soewandhie Surabaya The results of research on Organizational Capacity Development through the Implementation of Hospital Management Information Systems (SIMRS), it can be concluded that the obstacles faced by RSUD dr. Mohamad Soewandhie Surabaya is on the facilities and infrastructure that is still experiencing network and computer instability for the client is old or old. Conclusion: The clarity in the process and who is involved in the decision-making can be seen that the existing capacity building at the organizational level in the aspect of the decision-making process can be said to be going well.

Ave Maria (2017) The Implementation of Hospital Management Information Systems as One of the Strategies to Improve the Quality of Hospital Services. The research method used is descriptive qualitative analysis. The data collection used is interviews using interviews accompanied by observation techniques and literature. The data analysis technique used SWOT analysis. The results of the study can be seen that the application of the Hospital Management Information System at the Santo Borromeus Hospital in Bandung City is based on the four pillars of the information system, namely 1). Technoware / data processing devices, 2). Physical components: hardware, software, 3 ). Humanware / personal, 3). Infoware / data, and 4). Organiware / procedures. Barriers to the application of the Hospital Management Information System at the Santo Borromeus Hospital in Bandung City consist of human resource factors including HR characteristics, knowledge of technology/computers and skills in using computers. Technical factors include hardware (hardware), software (software), network connections. Communication channel factors include socialization, training, mentoring and management factors include organizational structure, SOPs, policies play a role in the successful implementation of hospital information systems. Conclusion: Barriers to the application of Hospital Management Information Systems at the Santo Borromeus Hospital in Bandung City consist of human resource factors including HR characteristics, knowledge of technology/computers and skills in using computers, technical factors include hardware, software ( software), network connections, communication channel factors include socialization, training, mentoring and Management includes organizational structure, SOPs, policies play a role in the successful implementation of hospital information systems. 
Fitriyanti Lestari (2017) The Effect of Work Culture, Competence, and Implementation of Hospital Management Information Systems on the Performance of Rama Hadi Hospital Employees The research design used in this study was a cross sectional sample of 86 administrative employees which indicated that the research respondents were: All employees at home Hospital Hospitality, Purwakarta Regency The results of SPSS calculation and data processing show that the total simultaneous influence of work culture, competence and SIMRS variables on performance (R2) is $76.9 \%$ while the rest is epsilon $(\varepsilon)$ or other influences that affect employee performance. in addition to work culture, competence and SIMRS are 23.1\%. This means that there are other aspects that can affect employee performance other than work culture, competence and SIMRS

Conclusion :

1. The work culture variable based on the perception of the majority of respondents, it can be concluded that the work culture variable is in fairly good criteria because as many as $54.9 \%$ of respondents perceive the answer to be quite good to very bad and $45.1 \%$ of respondents perceive it to be good to very good.

2. The competence variable is in fairly good criteria because as many as $50.3 \%$ of respondents perceive the answer to be quite good to very bad and $49.7 \%$ of respondents perceive it to be good to very good

Indra Gunawan (2013) Evaluation of Hospital Management Information System (SIMRS) Brebes Hospital in Readiness to Apply Online Hospital Information System (SIRS) Ministry of Health RI in 2013 This research is a type of research with a qualitative descriptive approach. The research subjects where the total number of research subjects were 33 respondents from several service units and objects to be studied/evaluated by researchers in this study was the Indonesian Ministry of Health's online SIRS application system. Data collection using data collection techniques In-depth interviews, namely conducting in-depth interviews with 33 respondents in each service unit of the Brebes Hospital and the documentation study using a documentation study in the form of report data at the Brebes Hospital in 2012. Results In 33 respondents, it is known that the education level of officers in each service unit at the Brebes Hospital must be from a D3 Medical Record education as much as $60.61 \%$ (20 respondents). Of the 32 respondents, the frequency distribution of the education level of the SIM RS officers in each service unit at the Brebes District Hospital is the D3 level of education with a percentage of $59.38 \%$. Of the 32 respondents, the frequency distribution of the details of the education level of RS SIM officers in each service unit at the Brebes District Hospital was the highest at the D3 nurse education level with a percentage of $37.50 \%$. For knowledge about the understanding of SIM RS, almost $100 \%$ of officers in each service unit at RSUD Brebes clearly understand about SIM RS. In accordance with the research objectives, which can be concluded in this study include:

1. The human resources of the RS SIM data input users are mostly from D3 Nursing staff.

2. The role of Human Resources for RS SIM data input users in each service unit at the Brebes Hospital, not all human resources input data on the RS SIM, and understand the integrated RS SIM and online SIRS reporting from the Ministry of Health of the Republic of Indonesia

3. The SIM computerized system for RS RSUD Brebes, for data input has not been carried out optimally, for the process and output of RS SIM data, in the process of making RL reports it is still manual because the SIM RS has not been integrated with the online SIRS reporting feature in the SIM RS menu. Meanwhile, SIMRS feedback has never been done by hospital management.

Manik Mahendra Sari, Guardian Yoki Sanjaya, Andreasta Meliala (2016) Evaluation of Hospital Management Information System (SIMRS) With Hot - Fit Framework The research design used was a single case study. The study was conducted in a private hospital specializing in type C surgery with a capacity of 25 beds, equipped with Emergency Room (IGD), outpatient, inpatient, pharmacy, radiology, laboratory, surgical installations, High Care Unit (HCU) services, hemodialysis 
and other support services. The results of the analysis show that there is a mis-fit between technology and humans which has an impact on the perception of less benefits for users. The inhibiting factors include SIMRS not in accordance with needs, the perception that using manual recording is easier and faster, the perception that the use of SIMRS adds to the workload, and the output of SIMRS is considered not relevant to user needs. However, strong organizational factors encourage the sustainable use of SIMRS such as work culture and leadership. SIMRS development can be directed to support organizational management and quality of medical services. The factors that positively influence the use of SIMRS are user satisfaction, organizational support, information quality, user satisfaction and the direct benefits that can be felt. The use of SIMRS can provide benefits for user performance and patient care. The existence of a mismatch between technology and humans has an impact on the perception of less benefits for users. The inhibiting factors include SIMRS is not in accordance with the needs, the perception that using manual recording is easier and faster, the perception that the use of SIMRS adds to the workload, the SIMRS output is considered not relevant to the user's needs. Strong organizational factors supported by leadership at various levels of the organization can encourage the use of SIMRS on an ongoing basis, so that the use of SIMRS can become a work culture.

Suyanto, Hidayat Taufiq, Indiati (2015) Factors Inhibiting the Implementation of Hospital Management Information Systems at RSUD Blambangan Banyuwangi This research is a qualitative descriptive study with interviews and observations as data collection methods in the period September to October 2014. The results identified three main root causes of completeness standard operating procedures (SPO), clarity of main tasks and functions, as well as ineffective supervision as the cause of SIMRS not being optimally maximized. As a first step, the Hospital has developed 12 SOPs through a process of review and testing which will be followed up with an ongoing evaluation of implementation. Conclusion: The implementation of the SOP SIMRS that has been produced requires continuous evaluation and maintenance and even revision of improvements based on the results of the evaluation study $(2,9,10)$. Making the SIMRS SOP is the beginning of the solution to the problems in the implementation of computer-based SIMRS at the Blambangan Hospital. It is necessary to conduct further and in-depth research on the factors that influence the acceptance of computer-based SIMRS in Blambangan Hospital

Dedy Setyawan (2016) Analysis of the Implementation of Utilization of Hospital Management Information Systems (SIMRS) at Kardinah Tegal Hospital, This type of research is a quantitative research with descriptive research methods, namely finding a deeper picture of the utilization of hospital management information systems (SIMRS) at Kardinah Hospital Tegal, research subjects where the total number of research subjects is 79 respondents from several service units and objects to be studied/evaluated by researchers in this study. From all activities carried out at Kardinah Tegal Hospital using a Management Information System (MIS) it has been well utilized, starting from inputting registration data, patient diagnosis, patient actions, and patient mutations have been in accordance with applicable SOPs, but the SIM has not been issued. make the most of it. Although the Management Information System (SIMRS) at Kardinah Hospital Tegal has not been utilized optimally, it does not become an obstacle in providing services to patients and in making decisions. The conclusion of this study is that although the Management Information System (SIMRS) at Kardinah Tegal Hospital has not been used optimally, it does not become an obstacle in providing services to patients and in making decisions.

International :

Anand Krishnan, Baridalyne Nongkynrih, Kapil Yadav, Satyavir Singh, and Vivek Gupta (2010) Evaluation Of Computerized Health Management Information System For Primary Health Care In Rural India Data for evaluation were collected through in-depth interviews with stakeholders, namely program managers (authors) and health workers. Health workers from AIIMS and NonAIIMS Primary Health Centers were interviewed to compare the manual with the computerized HMIS. Comparison of costs between the two methods is based on market costs. Resource utilization for manual and computerized HMIS was identified based on worker interviews. Result : There are no major hardware problems in the use of computerized HMIS. More than 95\% of the data is proven to be accurate. Health workers recognize the usefulness of HMIS in service delivery, data storage, work 
planning and reporting. For program managers, it provides better tools for monitoring and monitoring and managing data. Conclusion: The main advantage of computerization is that it saves health workers time in keeping records and making reports. The initial capital cost of computerization is recoverable within two years of implementation if the system is fully operational. Computerization has enabled the implementation of good systems for service delivery, monitoring and supervision

Mohammad Ali Abbasi Moghadam and Ahmad Fayaz-Bakhsh (2014) Hospital Information System Utilization in Iran: a Qualitative Study This phenomenological qualitative research was carried out in-depth personal interviews with senior hospital managers, and discussions were conducted in six to eight focus group members. The result is that problems in HIS isolation have arisen reported related to the following: software, hardware, manpower, management and training. About the latter In essence, it is stated that adequate continuing professional development programs do not exist for the proper use of computers in hospitals. To achieve the ultimate goal of HIS (eg increasing patient satisfaction and reducing hospital costs), it is necessary to make fundamental changes in the training system, and to obtain feedback from hospital personnel. Other measures include addressing software and hardware shortages and removals to strengthen enabling factors and refraining from constraining factors found in this study.

Dhyana Sharon Ross and R. Venkatesh (2016) Role of Hospital Information Systems in Improving Healthcare Quality in Hospitals Methods and Analysis: The Friedman test was conducted to determine the effect of implementing hospital information systems in hospitals to improve the quality of health services. Primary data collection was carried out by distributing questionnaires to PT Patient. A total of 214 samples were collected from a large corporate hospital in the capital city of Tamil Nadu, namely, Chennai and used for this research paper. The result is Implementing information systems in hospitals has a greater effect on improving the quality of health care among hospitals and this increases patient satisfaction. Conclusion : In the future, technological improvements will occur bringing tremendous growth in the healthcare sector which will reduce the burden on administrators and increase the level of quality and patient satisfaction.

Mehrdad Farzandipur, Fatemeh Rangraz jeddi and Esmaeil Azimi (2016) Factors Affecting Successful Implementation of Hospital Information Systems This study used a descriptive method in 20 clinical hospitals, the hospital's information system (HIS) was carried out in it. The hospital-named clinical and paraclinical users were the study group. 400 people were selected as samples in the scientific method and data were collected using a questionnaire consisting of three main human, managerial and organizational, and technological, through questionnaires and interviews. Results : Based on the findings, $302(75 \%)$ of the study group were women. This means that the respondent's experience is 10 years and the average age is 30 years. $243(2 / 61 \%)$ people are undergraduates, and $252(63 \%)$ people have ICDL certification. The average effectiveness of human factors is 3.5 points. Conclusion : Human factors including computer skills, feeling useful and feeling the ease of a hospital using information systems more effectively in the acceptance and successful implementation of hospital information systems; then the technology factor plays a bigger role. Recommended for the successful implementation of hospital information systems, most of these factors should be considered

\section{DISCUSSION}

Implementation is an action or implementation of a plan that has been prepared carefully and in detail. Implementation is usually done after the planning is considered perfect (Syaukani, 2016).

According to Irani (2013) "A computer-based information system is a system that uses computers to collect, summarize, filter and organize data in such a way that in addition to meeting the needs of routine data processing and reporting required by the company, it also meets the information needs of the company's managers.

According to Azwar (2010: 46) the quality of health services refers to the level of perfection of the appearance of health services that are held which on the one hand can satisfy service users and on the other hand the procedures for its implementation are in accordance with the professional code of ethics and standards that have been set. 
Hospital Management Information System is a computerized system that processes and integrates the entire flow of health care business processes in the form of a network of coordination, reporting and administrative procedures to obtain information quickly, precisely and accurately. A computer-based Management Information System (MIS) is a very important support tool, even absolute for hospital operations.

Therefore, the research conducted by Dedy Irawan, ME, Sy, Siska Novita (2014) with an article entitled "Management Information System at Harapan Bunda Prisewu Hospital Lampung", explains that in improving services at a hospital, a good management information system is needed. in order to make it easier for staff at the hospital in managing data. The result of their research is the production of reports related to data management and screen displays that can be used to manage data at the hospital.

Further research was carried out by Mellatul Husni and Maisa Putra (2019) with an article entitled "Analysis of Hospital Management Information System Implementation (SIMRS) in the Medical Record Work Unit at RSU 'Aisyiyah Padang" describing in detail the results of their research on which information system analysis from the results of the study there are three components used in their research, namely Human, Organization and Technology, and the results obtained are the application of a medical record SIM in terms of technology is quite good, although in the implementation of a medical record SIM there are still some obstacles but as long as it not too urgent can still be handled. In the technology component at Aisyiyah Hospital, the officers have tried to make the medical record SIM run smoothly.

Meanwhile, in the research journal article Andika Bayu Saputra (2016) with the title "Identification of Successful Factors in the Implementation of Hospital Management Information Systems", where this article suggests the success factors for implementing MIS in hospitals in this study the researchers used several variables, namely the quality of the system. , information quality, service quality, system use, user satisfaction, organizational structure, organizational environment and system benefits and the results obtained are SIMRS implementation at PKU Muhammadiyah Temanggung Hospital there are still some minor weaknesses that are not difficult to overcome. Some of the evaluations found were that the system still had errors during busy service hours, causing service activities to be hampered. Lack of personnel to handle system problems. Users who still do not understand how to use the system, so that the management information system at the hospital can run properly requires support and encouragement from the managerial side to SIMRS users and the availability of adequate facility conditions in the hospital environment to use SIMRS.

In contrast to Marsiana Afonso's research article, Dewi Ariyani Wulandari, Ronald (2017) with the title "Analysis of Hospital Management Information System Implementation at Tk III Hospital 04.06.03 Dr.R.Soetarto Yogyakarta" explained that SIM at Dr.R. Soetarto is still inadequate. Meanwhile, the support from the management has been very supportive. The availability of human resources in this hospital is still lacking because the average employees are civil servants and military so that their IT mastery is not so deep. In this study, it can be said that the TK III hospital 04.06.03 Dr. $\mathrm{R}$. Seotarto there is a problem, namely the incomplete infrastructure and Human Resources.

While the research conducted by Sadriani Hade, Abidin Djalla, Ayu Dwi Putri Rusman (2019) with the title "Analysis of the Application of Hospital Management Information Systems in an Effort to Improve Health Services at Andi Makkasau Hospital Parepare" explained that the Andi Makkasau Hospital Parepare previously used a manual system in inputting patient data so that the time required is very long and can reduce patient interest in the treatment process at the hospital. Seeing this, the management of Andi Makkasau Hospital switched to using a SIM so that services at the hospital run quickly and data collection is stored and runs well. The results showed that there was a difference between before and after the SIM-RS was introduced. Hospitals are expected to be able to maintain and develop the use of health service information technology for the community.

Subsequent research was carried out by Tiara Khairani, Heru Susilo, Riyadi (2013) with the article title "Implementation of Computer-Based Hospital Administration Information Systems to Improve Employee Performance (Study on Billing Systems Hospital Dr. Saiful Anwar Malang) explained that the implementation of administrative information systems in Dr. Hospital Saiful Anwar Malang has implemented a SIM but there are still some obstacles in operating a SIM in the hospital so that the Saiful Anwar hospital so that the researcher proposes that the obstacles that occur can be overcome by gradual system development in the administrative information system at the hospital. . 
The results obtained are an increase in employee performance, namely being able to complete work faster, minimizing errors and being able to complete work in accordance with the specified time. This is in accordance with the theory put forward by Hatta (2008) that information systems are carried out with processes. The process in question is the policies and procedures that must be followed and implemented by system users.

Research by Indriana Novita Suprapto, Wahyu Sulistiadi, Samijatun, Ismail Sangadji (2018) with the article title "Analysis of the Implementation of Information Technology Systems on the Performance of Outpatient Health Services at the Indonesian Christian University General Hospital", explains that outpatient services at UKI general hospitals are still using a manual system so it is necessary to implement SIMRS at the hospital in order to facilitate staff in providing services to patients. The results of their research are a study of documents containing the hospital flow system showing that the service flow system for patients at the Indonesian Christian University General Hospital, both as a whole and outpatient, has been in accordance with the service flow instructions that have been set by the Director General Yamed of the Indonesian Ministry of Health in 1997 according to with the theory of Ery Rustiyanto (2010), that a Hospital Management Information System (SIMRS) can be used as a strategic means to provide services that are oriented both to outpatients and inpatients to patient satisfaction.

The research conducted by Darmawanti, Idawati (2019) with the article title "Analysis of the Quality of Management Information Systems at the General Hospital of dr. Fauziah Bireun", explained that the application that was run was not appropriate because all parts of the hospital had not used SIMRS. SIMRS is only active at registration counters and laboratories, while inpatient and medical support, pharmacy and other management sections use the HMIS (health management information system) application. The result of their research is the lack of quality of SIMRS in terms of infrastructure and human resources. It is recommended that the management allocate special funds to the RBA or collaboration with the APBD in providing all infrastructure deficiencies, recruiting personnel, assertiveness from the management to improve discipline, providing rewards for those who carry out their duties well and punishment for those who neglect their duties.

Research conducted by Evi Maya Odelia (2018) with the article title "Development of Organizational Capacity Through the Implementation of Hospital Management Information Systems (SIMRS) to Improve the Quality of Health Services at RSUD dr. Mohamad Soewandhie Surabaya" explained that the Application of Hospital Management Information Systems at RSUD dr. Mohamad Soewandhie Surabaya based on the Director's Decree Number: 188.4/2984/436.7.8/2014 concerning Hospital Management Information System (SIMRS) RSUD dr. Mohamad Soewandhie Surabaya. With the Hospital Management Information System (SIMRS) in RSUD dr. Mohamad Soewandhie Surabaya, there are several significant changes, namely the annual income, the number of patient visits and the increasing community satisfaction index. Facilities and infrastructure in RSUD dr. Mohamad Soewandhie Surabaya is sufficient for operational activities but needs to be repaired or improved again by RSUD dr. Mohamad Soewandhie Surabaya. Although there are still many shortcomings in its supports such as old PCs and unstable networks, it is still able to meet all the needs needed to carry out operational activities optimally. The result of the research is Organizational Capacity Development Through the Implementation of Hospital Management Information System (SIMRS), it can be concluded that the obstacles faced by RSUD dr. Mohamad Soewandhie Surabaya is on the facilities and infrastructure that is still experiencing network and computer instability for the client is old or old.

Subsequent research was carried out by Ave Maria (2017) with the article title "Implementation of Hospital Management Information Systems as One of the Strategies for Improving the Quality of Hospital Services", explaining that the Santo Borromeus Hospital in Bandung City has implemented computer information systems since 2000 and can be accessed at any time. application properly so that the organizational structure can run well, although there are some obstacles or obstacles but can still be resolved properly. The results of the research are the results can be seen that the implementation of the Hospital Management Information System at the Santo Borromeus Hospital in Bandung City is based on the four pillars of the information system, namely 1). Technoware/data processing devices, 2). Physical components: hardware, software, 3). Humanware/personal, 3). Infoware/data, and 4). Organiware/procedure. 
The research conducted by Fitriyanti Lestari (2017) with the article title "The Influence of Work Culture, Competence, and Implementation of Hospital Management Information Systems on the Performance of Rama Hadi Hospital Employees", explains that the results of calculations and SPSS data processing show that the total influence simultaneously of work culture, competence and SIMRS variables on performance (R2) is $76.9 \%$ while the rest is epsilon $(\varepsilon)$ or other influences that affect employee performance other than work culture, competence and SIMRS is $23.1 \%$. This means that there are other aspects that can affect employee performance other than work culture, competence and SIMRS.

The next research is Indra Gunawan (2013) with the article title "Evaluation of Hospital Management Information System (SIMRS) Brebes Hospital in Readiness to Implement the Ministry of Health's Online Hospital Information System (SIRS) in 2013", explaining that the Hospital SIM Data FeedBack has never been analyzed data or data evaluation from the results of the SIMRS report, feedback from the management of the Brebes Hospital has never existed. Reports of patient visits from the results of the RS SIM output, both outpatient and inpatient, have never been used by the hospital management, have never been analyzed and evaluated. The management is more confident in the manual process compared to the output results from the RS SIM, because the results between the manual and the RS SIM are far different in number. Our reporting is only limited to external reporting obligations, namely online SIRS reporting. made by the medical records analysis and reporting section. The results of the research are the results of the study indicate that the preparation of HMIS in each service unit of the Brebes Hospital which will be integrated with the online HIS report, in terms of Human Resources, accommodation, Standard Operating Procedures and hospital director policies are generally not ready. The role of HR users of HMIS data entry in each service unit at the Brebes Hospital does not perform HMIS data entry and does not understand the online HIS report at the Indonesian Ministry of Health.

Subsequent research was carried out by Manik Mahendra Sari, Guardian Yoki Sanjaya, Andreasta Meliala (2016) with the title "Hospital Management Information System Evaluation (SIMRS) With a Hot - Fit Framework", explaining that the Hospital Management Information System produced was accurate and running. well, SIMRS users feel fast with the information generated. The results of their research are showing that there is a mis-fit between technology and humans which has an impact on the perception of less benefits for users. The inhibiting factors include SIMRS not in accordance with needs, the perception that using manual recording is easier and faster, the perception that the use of SIMRS adds to the workload, and the output of SIMRS is considered not relevant to user needs. However, strong organizational factors encourage the sustainable use of SIMRS such as work culture and leadership. SIMRS development can be directed to support organizational management and quality of medical services.

Subsequent research was carried out by Suyanto, Hidayat Taufiq, Indiati (2015) with the article title "Inhibiting Factors in the Implementation of Hospital Management Information Systems at Blambangan Hospital Banyuwangi" explaining that overall there are problems in almost all aspects, except the adequacy of human resources. The implementation of the RS SIM has not been followed by system structuring, cultural formation, device readiness, as well as system suitability studies. The results of their research study identified that the incompleteness of the SIMRS SOP was the root cause of the non-optimal implementation of the RS SIM. The factor of the incompleteness of the SIMRS SOP is important because the SOP is a formal, clear, complete, and detailed documented guide regarding the processes, tasks, and roles of each individual or group that are carried out daily in an organization.

The research conducted by Dedy Setyawan (2016) with the article title "Analysis of the Implementation of the Utilization of Hospital Management Information Systems (SIMRS) at Kardinah Tegal Hospital" the use of hospital information systems carried out at Kardinah Tegal Hospital using a Management Information System (SIM) has used properly, starting from inputting registration data, patient diagnosis, patient actions, and patient mutations have been in accordance with applicable SOPs, but the SIM has not been utilized optimally. Although the Management Information System (SIMRS) at Kardinah Hospital Tegal has not been fully utilized, it does not become an obstacle in providing services to patients and in making decisions.

Subsequent research conducted in India by Anand Krishnan, Baridalyne Nongkynrih, Kapil Yadav, Satyavir Singh, and Vivek Gupta (2010) with the article title "Evaluation Of Computerized 
Health Management Information System For Primary Health Care In Rural India", explained that the use of management information is very good and helps officers in completing work, there are no problems at all in the process of inputting data using SIMRS. The results of their research. Health workers recognize the usefulness of HMIS in service delivery, data storage, work planning and reporting is absolutely accurate

Research conducted by Mohammad Ali Abbasi Moghadam and Ahmad Fayaz-Bakhsh (2014) with the research title "Hospital Information System Utilization in Iran: a Qualitative Study" explains that the HIS development program is inadequate due to lack of software, hardware, manpower, and the lack of attention from the management so that the development of HIS in the hospital did not go well. Need to make fundamental changes in the training system, and get feedback from hospital personnel

Subsequent research was carried out by Dhyana Sharon Ross and R. Venkatesh (2016) with the article title "Role of Hospital Information Systems in Improving Healthcare Quality in Hospitals", explaining that the information system in the hospital is running well and plays an important role in improving the quality of the hospital. service in the hospital and increase patient satisfaction, there is no problem at all. The results of their study Implementing information systems in hospitals has a greater effect on improving the quality of health care among hospitals and this increases patient satisfaction.

Subsequent research conducted by Mehrdad Farzandipur, Fatemeh Rangraz jeddi and Esmaeil Azimi (2016) with the research title "Factors Affecting Successful Implementation of Hospital Information Systems" describes that in general humans have a greater influence in the implementation of information system implementation in hospitals, but if no training is carried out by hospital management it will slow down the information system, the average human resource in this study is able to operate information systems well and can help improve quality in the hospital

From the 19 research journals above, it can be seen that the implementation of a computerbased administrative information system plays an important role in supporting the improvement of service quality in a hospital. Of the 9 research journals above, they have implemented a computerbased administrative information system so that services at the hospital can run well. While the 10 journals in the end had several obstacles in implementing computer-based information systems, including 6 journals lacking personnel, less skilled personnel, and less disciplined and responsible personnel. Furthermore, there are 5 journals that have facilities and infrastructure constraints (unstable wifi network and system errors that often occur). And 5 journals of obstacles in the management section (there is no employee training and the correct application of SOPs). The best solution in order to be able to handle the above problems is to provide IT knowledge training to employees, improve the system and apply the correct SOP so that in the future the information system can be implemented and can be used in order to help simplify work and improve the quality of service in hospitals.

\section{CONCLUSION}

The results of a literature review on research that we have done in 20 journal articles on the Implementation of Computer-Based Administrative Information Systems to Improve Service Quality Performance in Hospitals there are obstacles in implementing computer-based information systems including lack of personnel, less skilled personnel, and less disciplined personnel. and responsibility, constraints on facilities and infrastructure (unstable wifi network and system often crashes) and obstacles in the management department (no employee training and proper SOP implementation). To deal with these problems can provide IT knowledge training to employees, improve the system and apply the correct SOP so that in the future information systems can be implemented and can be used in order to help simplify work and improve the quality of service in hospitals.

\section{CONFLICTS OF INTEREST}

Have no conflict of interest 


\section{REFERENCES}

Afonso, M., Dewi Ariyani Wulandari dan Ronald, (2017). Analisis Implementasi Sistem Informasi Manajemen Rumah Sakit Di Rumah Sakit Tk Iii 04.06.03 Dr.R.Soetarto Yogyakarta. Jurnal Kesehatan Masyarakat, 2017, 10.1

Darmawanti.,Idawati, (2009). Analisis Kualitas Sistem Informasi Manajemen Rumah Sakit Umum dr. Fauziah Bireun. Serambi Akademica Jurnal Pendidikan, Sains, dan Humaniora Vol. 7, No. 4, September 2019

Farzandipur, M., Fatemeh Rangraz jeddi and Esmaeil Azimi, (2016). Factors Affecting Successful Implementation of Hospital Information Systems. Multicenter study Health Inf Manag.2014;43(3):238. Original Paper / Acta Inform Med. 2016 Feb; vol 24(1): 51-55

Gunawan, I. (2013). Evaluasi Sistem Informasi Manajemen Rumah Sakit (Simrs) RSUD Brebes Dalam Kesiapan Penerapan Sistem Informasi Rumah Sakit (Sirs) Online Kemenkes Ri Tahun 2013. Kemenkes RI Tahun 2013, Jurnal Rekam Medis, 2013, 83.6

Hade, S., Abidin Djalla dan Ayu Dwi Putri Rusman, (2019). Analisis Penerapan Sistem Informasi Manajemen Rumah Sakit Dalam Upaya Peningkatan Pelayanan Kesehatan Di Rsud Andi Makkasau Parepare. Jurnal Ilmiah Manusia Dan Kesehatan Vol. 2, No. 2 Mei 2019

Husni, M.,Deni Maisa Putra, (2019). Analisis Implememntasi Sistem Informasi Manajemen Rumah Sakit (SIMRS) Pada Unit Kerja Rekam Medis Di Rsu 'Aisyiyah Padang. Jurnal Kesehatan Lentera 'Aisyiyah Vol 2., No. 1, Juni 2019

Irawan, D.,Siska Novita, (2014). Sistem Informasi Manajemen Rumah Sakit Harapan Bunda Pringsewu Lampung. Jurnal TAM (Technology Acceptance Model) Volume 2 Juli 2014

Khairani, T., Heru Susilo dan Riyadi, (2013). Implementasi Sistem Informasi Administrasi Rumah Sakit Berbasis Komputer Untuk Meningkatkan Kinerja Karyawan (Studi Pada Billing Systems Rsud Dr.Saiful Anwar Malang). Jurnal Administrasi Bisnis (JAB)| Vol. 6 No. 2 Desember 2013

Krishnan, A., Baridalyne Nongkynrih, Kapil Yadav, Satyavir Singh,and Vivek Gupta, (2010). Evaluation Of Computerized Health Management Information System For Primary Health Care In Rural India. Krishnan et al. BMC Health Services Research 2010, 10:310

Lestari, F. (2017). Pengaruh Budaya Kerja, Kompetensi, Dan Penerapan Sistem Informasi Manajemen Rumah Sakit Terhadap Kinerja Pegawai Rumah Sakit Rama Hadi. Artikel 2017. PhD Thesis. UNPAS

Maria, R,A. (2017). Penerapan Sistem Informasi Manajemen Rumah Sakit Sebagai Salah Satu Strategi Peningkatan Mutu Layanan Rumah Sakit. Artikel 2017. PhD Thesis. UNPAS

Moghadam, M, A, A., Ahmad Fayaz-Bakhsh, (2014). Hospital Information System Utilization in Iran: a Qualitative Study. Acta Medica Iranica, Vol. 52, No. 11 (2014)

Odelia, E, M. (2018). Pengembangan Kapasitas Organisasi Melalui Penerapan Sistem Informasi Manajemen Rumah Sakit (SIMRS) Untuk Meningkatkan Mutu Pelayanan Kesehatan di RSUD dr. Mohamad Soewandhie Surabaya. Kebijakan dan Manajemen Publik Volume 6, Nomor 1, JanuariApril 2018

Ross, D, S.,R. Venkatesh, (2016). Role of Hospital Information Systems in Improving Healthcare Quality in Hospitals. Indian Journal of Science and Technology, Vol 9(26), DOI: 10.17485/ijst/2016/v9i26/92686, July 2016

Saputra, A.B. (2016). Identifikasi Faktor-Faktor Keberhasilan Implementasi Sistem Informasi Manajemen Rumah Sakit. Jurnal Penelitian Pers dan Komunikasi Pembangunan Vol. 19 No.3 Februari 2016: 135-148

Sari, M, M., Guardian Yoki Sanjaya , Andreasta Meliala, (2016). Evaluasi Sistem Informasi Manajemen Rumah Sakit (Simrs) Dengan Kerangka Hot - Fit. Seminar Nasional Sistem Informasi Indonesia, 1 November 2016 
Setyawan, D. (2016). Analisis Implementasi Pemanfaatan Sistem Informasi Manajemen Rumah Sakit (SIMRS) Pada RSUD Kardinah Tegal. Indonesian Journal on Computer and Information Technology Vol 1 No 2 November 2016

Sharifian, R., Fatemeh Askarian, Mohtaram Nematolahi, and Payam Farhadi, (2014). Factors Influencin Nurses' Acceptance Of Hospital Information Systems In Iran: Applicatio Of The Unified Theory Of Acceptance And Use Of Technology. Multicenter study Health Inf Manag.2014;43(3):238 .

Suprapto, I, N., Wahyu Sulistiadi, Samijatun, dan Ismail Sangadji, (2018). Analisis Penerapan Sistem Informasi Teknologi Terhadap Kinerja Pelayanan Kesehatan Rawat Jalan Di Rumah Sakit Umum Universitas Kristen Indonesia. Jurnal Manajemen dan Administrasi Rumah Sakit Vol. 2, No. 1, April 2018

Suyanto., Hidayat Taufiq, Indiati, (2015). Faktor Penghambat Implementasi Sistem Informasi Manajemen Rumah Sakit di RSUD Blambangan Banyuwangi. Jurnal Kedokteran Brawijaya, Vol. 28, Suplemen No. 2, 2015

\section{References from Books:}

Taninas, N. (2017). Analisis Sistem Informasi Kesehatan Di Rumah Sakit Muhammadiyah Ahmad Dahlan Kediri.Strada School Of Health Science Public Health

\section{References from the Website:}

Azwar,A. (2010). Pengantar Administrasi Kesehatan, Jakarta: Bina Rupa Aksara dari http://kin.perpusnas.go.id/DisplayData.aspx?pId=840\&pRegionCode=MANADO\&pClientId=626 (Disarikan dari berbagai sumber).

DepKes RI. 2016. Profil Kesehatan Indonesia 2014 : Menuju Indonesia Sehat 2015. Jakarta : Departemen Kesehatan RI dari https://pusdatin.kemkes.go.id/resources/download/pusdatin/profilkesehatan-indonesia/profil-kesehatan-indonesia-2014.pdf (Disarikan dari berbagai sumber).

Kemenkes, RI. 2012. Profil Kesehatan Indonesia. Jakarta: Kementrin Kesehatan Republik Indonesia dari https://pusdatin.kemkes.go.id/resources/download/pusdatin/profil-kesehatan-indonesia/profilkesehatan-indonesia-2012.pdf (Disarikan dari berbagai sumber).

Notoatmojo, Soekidjo. 2010. Ilmu Kesehatan Masyarakat. Jakarta : Rineka Cipta.

Notoatmodjo, Soekidjo. 2010. Metodologi Penelitian Kesehatan. Jakarta : Rineka Cipta.

Tjiptono,(2010). Kualitas Pelayanan. Edisi III, Yogyakarta:CV. Andi Offset,2010 